Article

\title{
The Effects of Litter Layer and Topsoil on Surface Runoff during Simulated Rainfall in Guizhou Province, China: A Plot Scale Case Study
}

\author{
Qiuwen Zhou ${ }^{1,2, *} \mathbb{B}^{\mathbb{D}}, \mathrm{Xu}_{\text {Zhou }}{ }^{1,2}$, Ya Luo ${ }^{1,2}$ and Mingyong Cai ${ }^{3}$ \\ 1 School of Geographic and Environmental Science, Guizhou Normal University, Guiyang 550001, China; \\ zxzy8178@163.com (X.Z.); luoya2002@163.com (Y.L.) \\ 2 State Engineering and Technology Institute for Karst Desertification Control, Guizhou Normal University, \\ Guiyang 550001, China \\ 3 Satellite Environment Center of MEP, Beijing 100094, China; caimingyong@126.com \\ * Correspondence: zhouqiuwen@gznu.edu.cn; Tel.: +86-851-8322-7361
}

Received: 25 May 2018; Accepted: 9 July 2018; Published: 11 July 2018

\begin{abstract}
Litter layers and topsoil have important effects on surface runoff. To investigate these effects at the plot scale, artificial rainfall experiments were conducted on micro-runoff plots in Guizhou Province, China. Three types of plots were selected, the thin litter layer with low soil bulk density type (T-L type), the thick litter layer with high soil bulk density type (T-H type), and the moderate litter depth and soil bulk density type (M type), and three artificial rainfall intensities $(30 \mathrm{~mm} / \mathrm{h}$, $70 \mathrm{~mm} / \mathrm{h}, 120 \mathrm{~mm} / \mathrm{h}$ ) were used. The runoff volume was largest in the T-H type plot at different rainfall intensities and durations. Runoff in the $M$ type plot had characteristics of both the T-L and $\mathrm{T}-\mathrm{H}$ type plots. The runoff yielding speed was significantly higher and the runoff yielding time was significantly lower in the T-H type plot. In general, the runoff coefficient was the smallest in the T-L type plot and largest in the T-H type plot. The variations in the runoff coefficient were $15.6 \%$, $19.3 \%$, and $5.8 \%$ for the T-L, T-H, and $\mathrm{M}$ type plots respectively. The results of this study can improve the understanding of surface runoff processes at the plot scale under different litter and surface soil conditions.
\end{abstract}

Keywords: runoff; simulated rainfall; plot scale; litter layer; topsoil; karst

\section{Introduction}

A litter layer is typically composed of dead leaves, twigs, small branches, and other fragmented organic material, and influences the hydrological processes that operate in forested watersheds [1]. The regulation of the litter layer includes the interception, throughfall, and stemflow, which regulate soil evaporation, increase permeability, reduce overland flow, and create a rapid-flow component within the litter layer [2-4]. The simultaneous operation of these processes causes the litter layer to affect both short-term runoff and long-term water balance within a hydrological cycle. Not only the litter layer but also the topsoil has a notable impact on hydrological processes. The topsoil state regarding water movement into the soil mass may affect evaporation, infiltration, and distribution of topsoil [5]. Further, various runoff generating processes (saturation excess overland flow, infiltration excess overland flow, and return flow) are highly regulated by the topsoil state [6,7]. In short, as one of the hydrological elements, the generation and dynamics of surface runoff are significantly affected by the state of the litter layer and the topsoil.

Several studies examined how surface runoff is regulated by the extent of litter coverage. To investigate the influence of the litter layer and undergrowth intercrops on surface runoff and 
soil erosion, experimental field plots were monitored by Liu et al. [8] over one rainy season in a rubber monoculture and a rubber/tea agroforestry system. In a simulated rainfall experiment in runoff plots, Li et al. [4] investigated the effect of litter cover on surface runoff in northern China. Miyata et al. [9] examined the effects of forest floor coverage on overland flow generation and soil erosion in mature Japanese cypress plantations with different coverage conditions. Prosdocimi et al. [10] evaluated the immediate effectiveness of the litter layer in reducing surface runoff generation in Mediterranean vineyards. These works have greatly enriched the understanding of the relationship between the litter layer and surface runoff. In addition to litter layers, the runoff effect of surface soils has attracted the attention of many researchers in the hydrology field. In terms of runoff generating processes, overland flow generation mechanisms affected by topsoil treatment and Hortonian overland flow is responsible for significant amounts of soil loss in Mediterranean geomorphological systems [11]. Sorbotten et al. [12] observed that in an Acrisol on a forested hillslope with a monsoonal subtropical climate, the topsoil responded quickly to rainfall events, causing frequent cycles of saturation and aeration of soil pores. Compaction and destruction of the topsoil structure by machinery, especially at harvest, is important in initiating runoff [13]. In fact, the runoff effect of topsoil also has a scale effect. At sites with intensive grazing small-plot devices deliver significantly higher runoff coefficients than large-plot devices, due to topsoil compaction and the shortened flow path [14]. In terms of the impact of revegetation on runoff, Zhang et al. [15] showed that revegetation with artificial plants improved topsoil hydrological properties but intensified deep-soil drying in northern Loess Plateau, China.

Guizhou Province has the largest area of karst landforms in China, with the karst area accounting for $64.2 \%$ of the total area of the province [16]. The karst hydrological system consists of two systems, surface and underground, and surface water flow is connected with an extensive subsurface drainage or karst conduit network by fissures, sinkholes, and swallets $[17,18]$. In a karst environment, due to the slow rate of formation of soil, rainfall and subsequent surface runoff may scour the topsoil, leading to soil erosion and consequent rocky desertification $[19,20]$. Precipitation in a karst area quickly infiltrates the ground and enters the underground system. Thus, it cannot support plant growth. Areas with a low density of surface streams often have high soil erosion and a more severe problem of rocky desertification [21]. Thus, surface runoff is one of the key factors affecting the ecological problems associated with karst regions, such as rocky desertification and sparse vegetation that may require restoration. Furthermore, due to the shallowness of the soil in the karst area, the litter layer and topsoil affect the formation of surface runoff. Therefore, it is necessary to conduct in-depth research on surface runoff in Guizhou Province.

Since the 1990s, there has been a series of studies on karst surface runoff [22-27]. These studies focused on the runoff generation on limestone slopes [28,29], the effects of the proportion of bare bedrock and degree of underground pore fissures on surface runoff [30], and the research methods for surface runoff in karst areas [31,32]. However, to the best of our knowledge, there have not been many studies on the combined effects of litter layers and topsoil on surface runoff processes, especially in karst areas.

In this study, three plots with similar climatic conditions and vegetation, but with different litter and topsoil states, were selected in Guizhou Province, China. Simulated rainfall experiments were conducted and the runoff characteristics of the three plots were compared. Our goal was to determine the differences in surface runoff characteristics under different litter and surface soil combinations at the plot scale in a case study at the three sites in Guizhou Province.

\section{Materials and Methods}

\subsection{Study Area}

The experimental sites were located in Huaxi District in Guiyang City, Guizhou Province in southwestern China. The region has a subtropical moist monsoon climate and an annual precipitation of $1129 \mathrm{~mm}$. The mean annual temperature is $15.3^{\circ} \mathrm{C}$ and the monthly averages range from $-7.3^{\circ} \mathrm{C}$ to 
$35.1^{\circ} \mathrm{C}$. The elevation varies from 1002 to $1627 \mathrm{~m}$ above sea level and the relief is dominated by hills. The landforms of the study area can be divided into three types: karst landforms, non-karst landforms, and semi-karst landforms. In the karst area, the soils are calcareous soils developed from limestone and the soil layer is thin and discontinuous. In the non-karst area, the soil type is yellow soil developed from sandstone and the soil layer is thick. In the semi-karst area, the soil type is yellow soil developed from dolostone and the soil layer is thinner than that in the non-karst area. The locations of the three plots are shown in Figure 1.

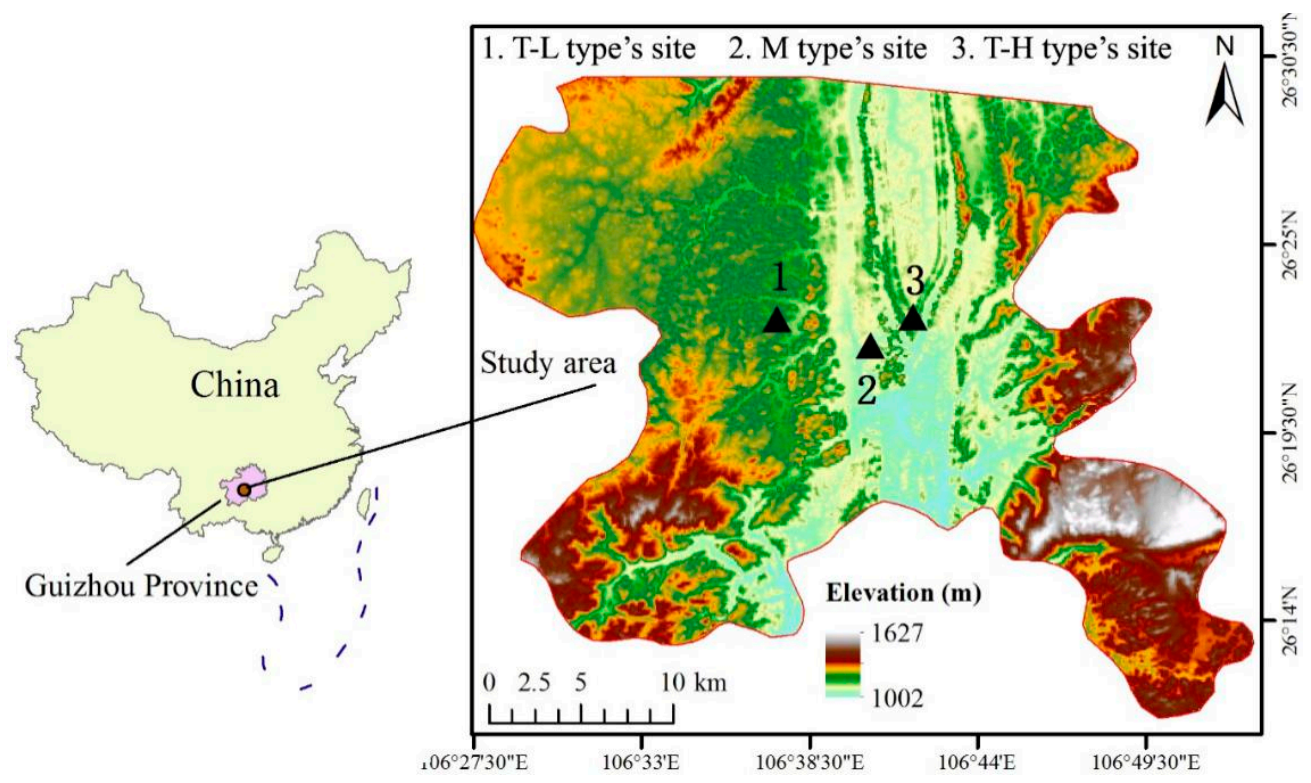

Figure 1. The location and elevation of the study area.

\subsection{Description of Plots}

In this work, three experimental sites corresponding to the three litter and surface soil combination types were selected. The first type is the thin litter layer with low soil bulk density (T-L type), the second type is the thick litter layer with high soil bulk density (T-H type), and the third type is the moderate litter depth and soil bulk density ( $\mathrm{M}$ type). To ensure the consistency of climatic conditions, the three sites were selected such that the distance between any sites was not more than $10 \mathrm{~km}$. The main tree species at all sites is Pinus massoniana. The T-L, T-H, and M types have an average tree age of 20, 12 , and $17 \mathrm{y}$, an average tree height of 15,13 , and $16 \mathrm{~m}$, and a canopy density of $0.85,0.95$, and 0.95 , respectively. All three sites have a small amount of natural understory vegetation on the forest floor and the soil is mostly covered by a litter layer of needles. We set a group of nine runoff plots at each site for a grand total of 27 runoff plots. The runoff plots at each site were adjacent to each other. The average characteristic values of each runoff plot group at the sites are listed in Table 1 . The experiments were conducted in October 2016, which is in the early dry season. The soil moisture was generally low and changed slightly because of the seasonal drought. Hence, the antecedent soil moisture differences did not affect the simulation experiments.

Table 1. Characteristics of liter layer and topsoil.

\begin{tabular}{ccccc}
\hline Site & $\begin{array}{c}\text { Litter Depth } \\
(\mathbf{m m})\end{array}$ & $\begin{array}{c}\text { Litter Mass } \\
\left(\mathbf{t} / \mathbf{h m}^{\mathbf{2}}\right)\end{array}$ & $\begin{array}{c}\text { Soil Bulk } \\
\text { Density } \mathbf{( g / \mathbf { c m } ^ { 3 } )}\end{array}$ & $\begin{array}{c}\text { Slope } \\
\text { Gradient }\end{array}$ \\
\hline T-L type & 54.16 & 30.52 & 1.515 & $40^{\circ}$ \\
T-H type & 133.617 & 40.60 & 2.098 & $39^{\circ}$ \\
M type & 68.85 & 45.26 & 1.742 & $37^{\circ}$ \\
\hline
\end{tabular}


The experiments were carried out using a portable rainfall simulator. The nozzle was set on a steel frame at the height of $2 \mathrm{~m}$. At this height, the nozzle generated a constant intensity of rainfall within a $1 \mathrm{~m}$ radius around the rainfall simulator. The circular area was marked on the soil surface, and then a $60 \mathrm{~cm} \times 100 \mathrm{~cm}$ rectangular runoff plot was set in the center of the circle. The plot boundaries were defined using $30 \mathrm{~cm}$ high iron sheets that were inserted into the ground to a depth of $10 \mathrm{~cm}$. A V-shaped groove was placed at the lower end of the plot to collect runoff (Figure 2). Finally, clear water was supplied through a $2.5 \mathrm{~cm}$ diameter high-pressure hose by a pump. The pump was powered by a $2.0 \mathrm{Kw} / 220 \mathrm{~V}$ gasoline generator. The rainfall intensity was controlled by a flow meter attached to the hose. The correspondence between rainfall intensity and flow has been determined by our previous experiments.

\subsection{Data Acquisition and Processing}

Each simulated rainfall event lasted $30 \mathrm{~min}$ and runoff volume data were collected every $3 \mathrm{~min}$. When continuous water flow began to appear in the V-shaped groove, the runoff generation time was recorded. Based on the rainfall intensity and rainfall frequency in this area, three rainfall intensity values were selected: $30 \mathrm{~mm} / \mathrm{h}, 75 \mathrm{~mm} / \mathrm{h}$, and $125 \mathrm{~mm} / \mathrm{h}$. The corresponding three rainfall intensity experiments were conducted on each plot and three replications were made for each rainfall intensity. Thus, a total of 27 rainfall experiments were conducted (3 litter layer and topsoil combination types $\times 3$ intensities $\times 3$ replicates). Finally, to reduce the experimental error and obtain valid data for the analysis, we averaged the data of each replicate.


Figure 2. Micro-runoff plot setup in the forest.

\section{Results}

\subsection{Surface Runoff Changes under Different Litter Layer and Topsoil Combination Conditions}

Figure 3 shows that runoff is typically greater in the T-H type than in the T-L type or $\mathrm{M}$ type at various rainfall intensities. At the three sites, runoff first increased notably and then reached a steady state. When the rainfall intensity was $30 \mathrm{~mm} / \mathrm{h}$, the runoff at an early stage at three different litter layer and topsoil combination conditions was roughly the same. The runoff peaked at $9 \mathrm{~min}$ in the T-L type, but it reached its maximum at $18 \mathrm{~min}$ in the T-H type and at $24 \mathrm{~min}$ in the $\mathrm{M}$ type. The runoff in the T-H type fluctuated the most during the entire rainfall event and this runoff value was always the largest one. The maximum value of the $\mathrm{T}-\mathrm{H}$ type was 1.62 times that of the $\mathrm{M}$ type and 1.78 times that of the T-L type. When the rainfall intensity was $75 \mathrm{~mm} / \mathrm{h}$, the increasing trend of the runoff in three litter layer and topsoil combination conditions was consistent and stable. The T-H type had the largest runoff, followed by the $\mathrm{M}$ type and the T-L type, respectively. When the rainfall intensity was $120 \mathrm{~mm} / \mathrm{h}$, the runoff at the T-H type increased rapidly at the beginning of the rainfall 
event and reached its maximum at $18 \mathrm{~min}$. This maximum was 1.55 times that at the $\mathrm{M}$ type and 1.99 times that at the T-L type. The runoff at the T-L and M type increased steadily with a small gap. When the continuous runoff reached a peak, the runoff at the T-L and M type maintained the steady state. The runoff at the T-H type was always the highest under different rainfall intensities and durations. The runoff at the T-L type was typically the smallest. The increase in runoff became smaller with the increase in the rainfall duration. The runoff at the $M$ type was typically between the runoff values at the T-L type and T-H type.
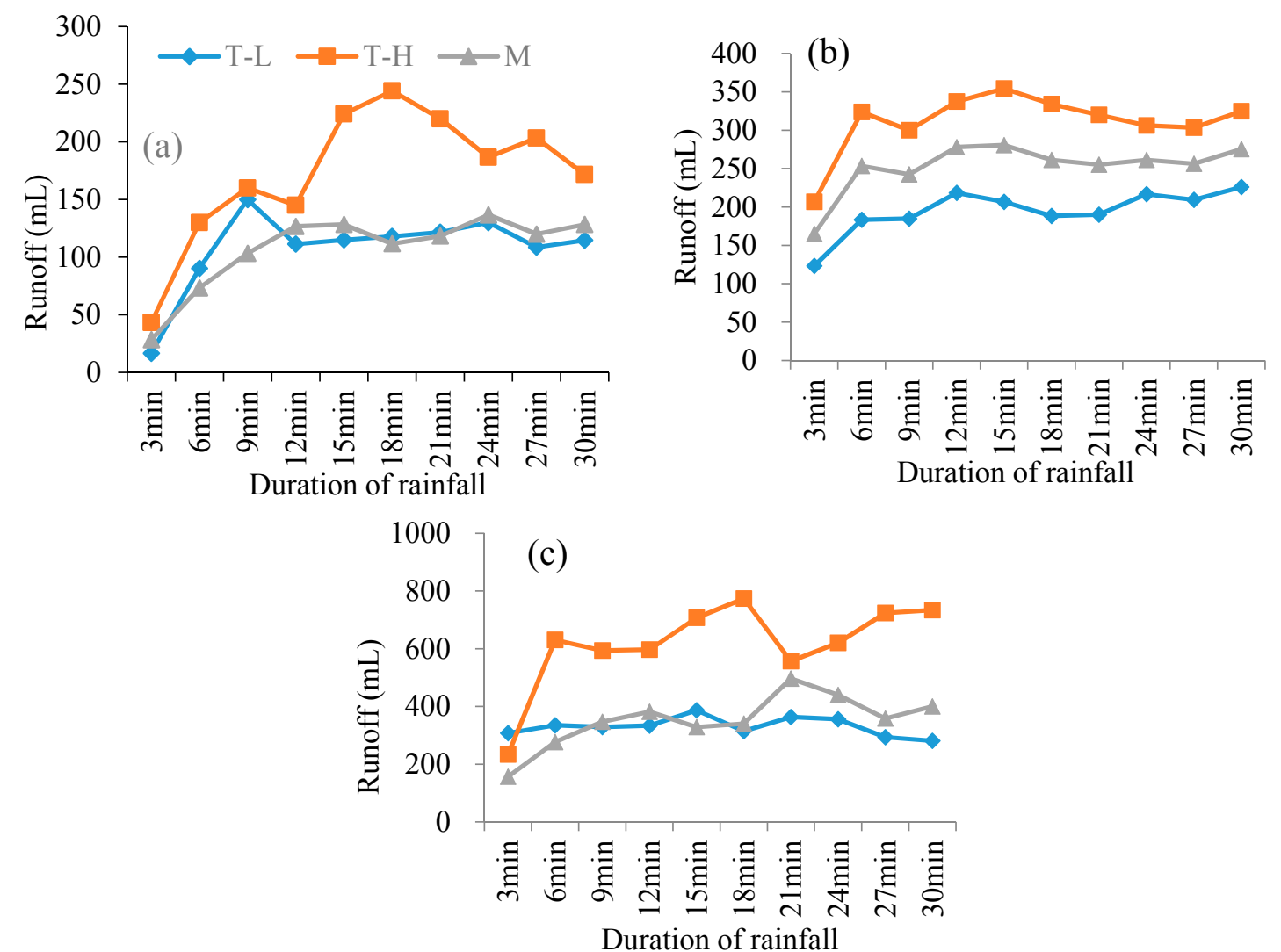

Figure 3. Runoff changes under different surface landscape conditions. (a) $30 \mathrm{~mm} / \mathrm{h}$ rainfall intensity; (b) $75 \mathrm{~mm} / \mathrm{h}$ rainfall intensity; and (c) $120 \mathrm{~mm} / \mathrm{h}$ rainfall intensity. T-L stands for thin litter layer with low soil bulk density, T-H stands for thick litter layer with high soil bulk density, and M stands for moderate litter depth and soil bulk density.

\subsection{Surface Runoff Changes under Different Rainfall Intensity}

To understand the effect of rainfall intensity on surface runoff, this section analyzes the variations in surface runoff for the T-L, M, and T-H types for the rainfall intensities of $30 \mathrm{~mm} / \mathrm{h}, 75 \mathrm{~mm} / \mathrm{h}$, and $120 \mathrm{~mm} / \mathrm{h}$, respectively (Figure 4). For the T-L type (Figure 4a), under the condition of heavy rainfall $(120 \mathrm{~mm} / \mathrm{h})$, the runoff reached a large value at the early stage of rainfall. In contrast, under the conditions of small and medium rainfall intensity $(30 \mathrm{~mm} / \mathrm{h}$ and $75 \mathrm{~mm} / \mathrm{h}$, respectively), the runoff took a long time to reach a large value. For the T-H type (Figure $4 \mathrm{~b}$ ), the runoff was relatively stable when the rainfall intensity was $30 \mathrm{~mm} / \mathrm{h}$ and $75 \mathrm{~mm} / \mathrm{h}$. However, the runoff fluctuated greatly when the rainfall intensity was $120 \mathrm{~mm} / \mathrm{h}$ and the maximum runoff at this intensity was 2.18 times the maximum runoff at $75 \mathrm{~mm} / \mathrm{h}$ and 3.1 times the maximum runoff at $30 \mathrm{~mm} / \mathrm{h}$. In the early stage of rainfall ( $3 \mathrm{~min}$ ), the runoff for the T-H type under the heavy rain intensity was not significantly different from the runoff at the medium and small rainfall intensities. However, after a certain period (6 $\mathrm{min})$, the runoff under the highest rainfall intensity reached a much larger value and increased rapidly with rainfall duration (Figure $4 b$ ). For the $M$ type (Figure 4c), the trend of runoff was similar 
for three rainfall intensities. When the rainfall intensity was $120 \mathrm{~mm} / \mathrm{h}$, the maximum runoff was 1.6 times the maximum runoff at $75 \mathrm{~mm} / \mathrm{h}$ and 3.6 times the maximum runoff at $30 \mathrm{~mm} / \mathrm{h}$. Figure $4 \mathrm{c}$ shows that the runoff for the $M$ type increased with the increase in rainfall intensity and reached a steady state after attaining its maximum value. The effect of rainfall intensity on surface runoff for the $\mathrm{M}$ type was limited to a change of magnitude. There was no significant difference in the surface runoff pattern between the rainfall intensities for the $M$ type (Figure $4 \mathrm{c}$ ).

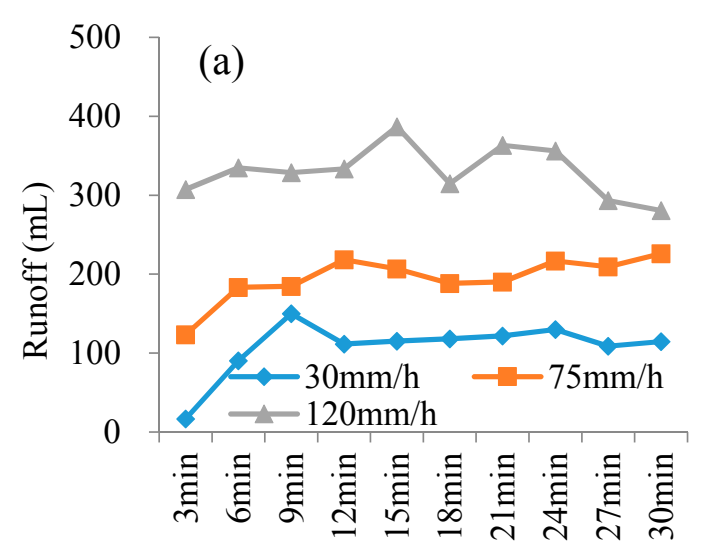

Duration of rainfall

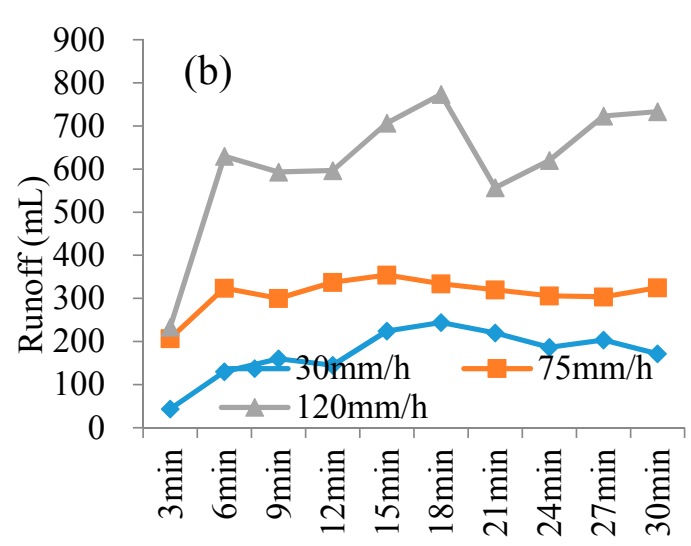

Duration of rainfall

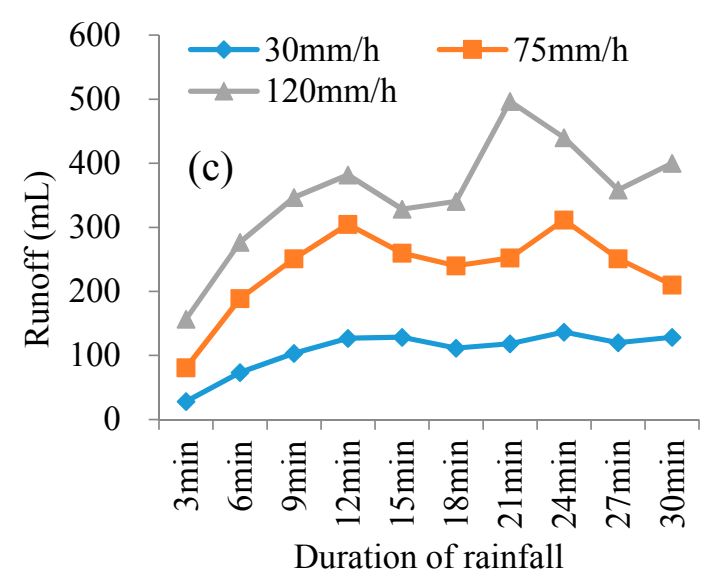

Figure 4. Runoff variations under different rainfall intensities. (a) T-L type; (b) T-H type; and (c) M type.

\subsection{Runoff Yield Characteristics under Different Litter Layer and Topsoil Combination Conditions}

Figure 5a shows that the runoff yielding times for different litter layer and topsoil combination conditions are 1-4 min. Under the same rainfall intensity, the T-H type had the shortest runoff yield time. When the rainfall intensity was $120 \mathrm{~mm} / \mathrm{h}$, this site generated runoff in $0.9 \mathrm{~min}$. The runoff yielding time for the $\mathrm{M}$ type was longer than that for the $\mathrm{T}-\mathrm{H}$ type, but runoff was generated within $1.51 \mathrm{~min}$ at the rainfall intensity of $120 \mathrm{~mm} / \mathrm{h}$. The T-L type had the longest runoff yielding time at the rainfall intensity of $30 \mathrm{~mm} / \mathrm{h}$. Under this intensity, it took $3.27 \mathrm{~min}$ to generate runoff for the T-L type, $2.37 \mathrm{~min}$ for the $\mathrm{M}$ type, and $1.7 \mathrm{~min}$ for the T-H type. With increasing rainfall intensity, the runoff yielding time of the three sites gradually shortened and the runoff yielding speed (Figure 5b) gradually increased. The T-H type had the highest runoff yielding speed and the T-L type had the smallest runoff yielding speed. In summary, the runoff yielding time for the T-H type was significantly shorter than the time for the T-L type or the $\mathrm{M}$ type and the runoff yielding speed for the T-H type was significantly higher than the rate for the T-L type or the M type. 

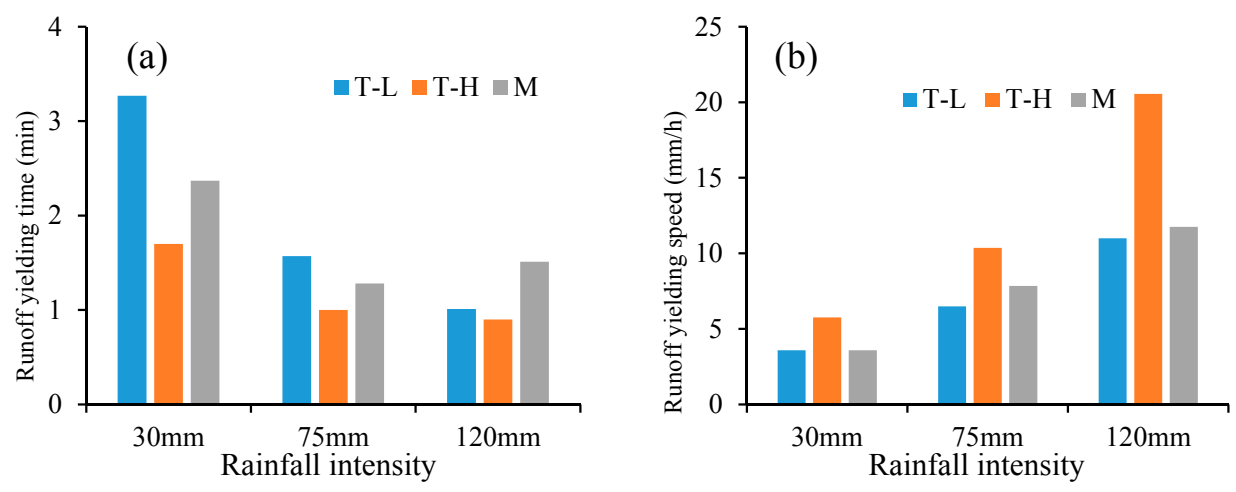

Figure 5. Runoff yielding time (a) and rate (b) at different sites. T-L stands for thin litter layer with low soil bulk density, T-H stands for thick litter layer with high soil bulk density, and M stands for moderate litter depth and soil bulk density.

\subsection{Surface Runoff Coefficient under Different Litter Layer and Topsoil Combination Conditions}

Figure 6a shows that the runoff coefficient of the T-L type was the smallest and the runoff coefficient of the T-H type was the largest. However, at the rainfall intensity of $30 \mathrm{~mm} / \mathrm{h}$, the runoff coefficient of the $\mathrm{M}$ type was slightly lower than the coefficient of the T-L type. Under the rainfall intensity of $120 \mathrm{~mm} / \mathrm{h}$, the runoff coefficient of the $\mathrm{M}$ type was not significantly different from that of the T-L type. At the T-L type and the T-H type, the runoff coefficient at the rainfall intensity of $75 \mathrm{~mm} / \mathrm{h}$ was significantly lower than the rainfall coefficients of the other two rainfall intensities. This difference was not obvious for the $\mathrm{M}$ type. The effect of rainfall intensity on the runoff coefficient was insignificant. Under three rainfall intensities, the variation in the runoff coefficient was $15.6 \%$ for the T-L type, $19.3 \%$ for the T-H type, and $5.8 \%$ for the M type.
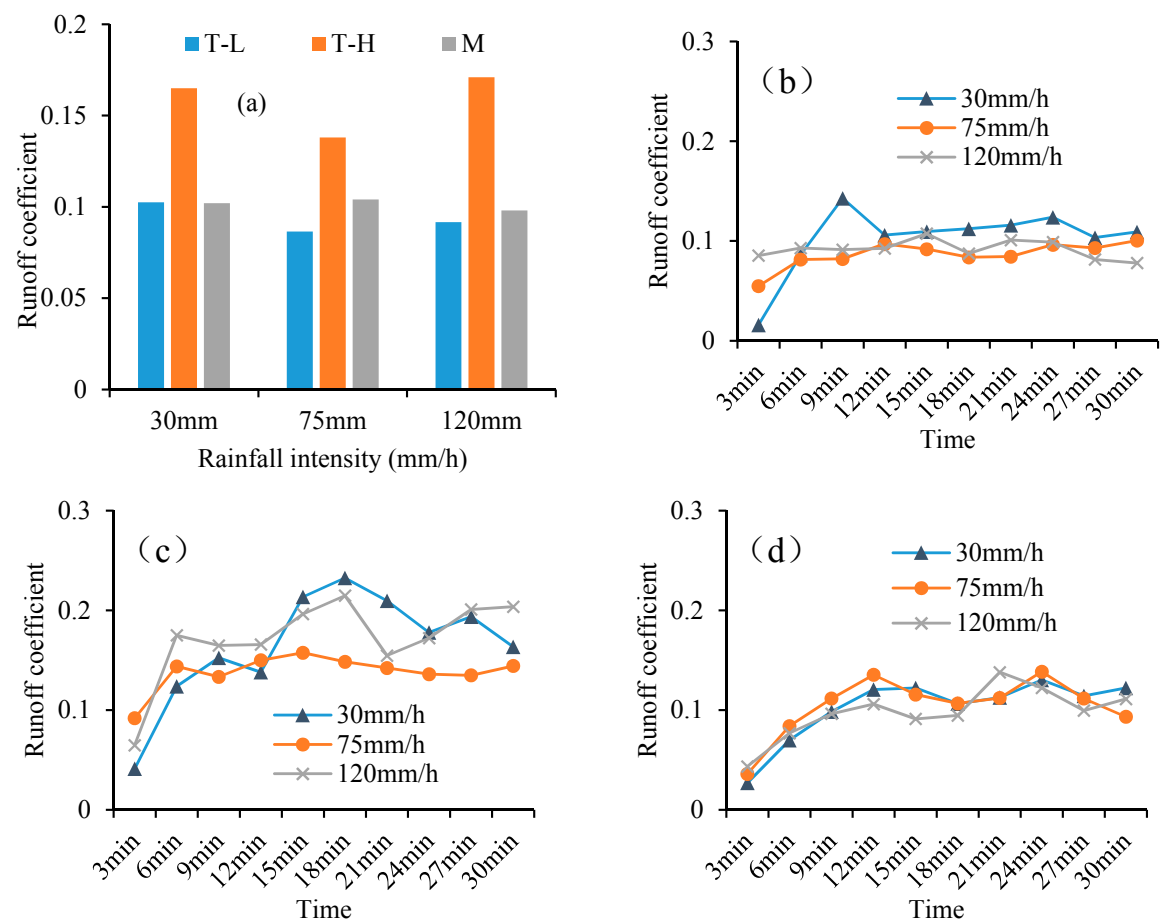

Figure 6. The general characteristics of the runoff coefficient (a) and the variations in the runoff coefficient with time for the T-L type (b); T-H type (c); and M type (d) plots. T-L stands for thin litter layer with low soil bulk density, T-H stands for thick litter layer with high soil bulk density, and M stands for moderate litter depth and soil bulk density. 
In general, there were some differences in the variation of the runoff coefficient at different sites. After $6 \mathrm{~min}$ of rainfall, in general, the runoff coefficient was close to its maximum value for the T-L type (Figure $6 \mathrm{~b}$ ). Thereafter, the runoff coefficient basically remained stable. For the T-H type (Figure $6 \mathrm{c}$ ), the runoff coefficients peaked at $\sim 18 \mathrm{~min}$ after the rainfall began. For the $\mathrm{M}$ type (Figure $6 \mathrm{~d}$ ), the runoff coefficient reached its maximum at $12 \mathrm{~min}$ and remained basically stable thereafter. The runoff coefficient of the T-H type fluctuated substantially with different rainfall intensity values. The runoff coefficient of the T-L type fluctuated less and the runoff coefficient produced by different rainfall intensities at different points in time showed no obvious differences. In summary, the runoff coefficients of the T-H type were significantly larger than those of the T-L and M types.

\section{Discussion}

\subsection{Influence of Litter Layer Conditions on Surface Runoff}

Under normal circumstances, as rainfall intensity increases, the runoff coefficient continually increases, decreases, or remains stable, and the rainfall intensity and runoff coefficient reflect a stable relationship. In this study, the runoff coefficients for the T-H type and the T-L type were smaller at the rainfall intensity of $75 \mathrm{~mm} / \mathrm{h}$ than at $30 \mathrm{~mm} / \mathrm{h}$ or $120 \mathrm{~mm} / \mathrm{h}$ and the relationship between the rainfall intensity and the runoff coefficient was not stable. However, the runoff coefficient for the $M$ type was basically stable under different rainfall intensities. The analysis of the differences in the individual plots showed that there were some differences in litter thickness and the volume between the three types. The litter thickness was higher at the T-H and T-L plots than at the M plots and the litter thickness was the largest at the T-H plots.

The analysis of the characteristics of the litter showed that litter coverage plays an important role in runoff generation in a small-area runoff plot. When the rainfall intensity is low, most of the rainfall remains on the surface of the undecomposed litter and flows down the slope as it accumulates on the surface. In this case, the litter plays the role of a conduit and the continuous leaf litter on the slope surface forms a flow channel for surface runoff. As a result, more surface runoff is generated and the runoff coefficient becomes larger.

The sample sites selected in this study were all in the Pinus massoniana forest. Because of the elongated undecomposed litter of this species (pine needles), the guiding effect on water flow was more obvious. However, the ability of the litter to guide the flow of water was limited. Under the medium rainfall condition $(75 \mathrm{~mm} / \mathrm{h})$, the amount of rainwater on the litter reaches its upper limit and water moves downward under the force of gravity, escaping the surface water flow channel formed by the litter. The water provided by the subsequent rainfall continues to drip beneath the water flow, thereby cutting off the water flow channel on the slope surface, increasing the volume of infiltration and reducing surface runoff and the runoff coefficient. When the rainfall intensity increases further $(120 \mathrm{~mm} / \mathrm{h})$, the larger rainfall intensity makes it easier for the moisture content of the mineral soil layer to reach saturation or the rainfall intensity exceeds the infiltration capacity of the soil layer. In this case, the infiltration capacity may decrease and a large amount of rainwater may become surface runoff. Under these circumstances, the runoff coefficient may be relatively large. However, this discussion is based only on a small number of existing research results, combined with experimental observations and an analysis of possible causes. Thus, experimental errors, sample selection, and other accidental uncertainties cannot be completely ruled out. In follow-up studies the role and significance of the litter layer, especially the undecomposed layer, for surface runoff at the plot scale needs to be further explored, and the nonlinear relationships of runoff with rainfall intensity and slope gradient need to be analyzed. This will further reveal the formation and evolution mechanisms of slope runoff under different landscape conditions. 


\subsection{Influence of Topsoil Conditions on Surface Runoff}

The results show that the surface runoff volume and runoff yielding speed of T-H are greater than those of the other types (Figures 3 and 5) and the runoff yielding time is less than that of the other two types (Figure 5). The soil bulk density for the T-H type is relatively large, meaning that the soil porosity is small and saturation is easily reached or the permeability coefficient is small and the rainfall intensity easily exceeds the infiltration rate, resulting in conversion of most of the precipitation to surface runoff. In contrast, the small bulk density of the other two types leads to the easy infiltration of the precipitation, resulting in a relatively small surface runoff value. Due to the large runoff volume of the T-H type, within the same time frame, the runoff yielding speed of the T-H type is also greater than the other two types. Similarly, due to the large soil bulk density of the T-H type and the low infiltration rate, surface runoff is relatively easily generated. Thus, the runoff yielding time is shorter and the runoff coefficient is larger in the T-H type than in the other types.

Although soil bulk density affects surface runoff, surface runoff is mainly determined by geological conditions. The study area is in a karst region, but karst is an extremely heterogeneous medium with varying lithology and sporadic non-carbonate areas. Although it is a carbonate rock, the landscape and soil conditions for limestone, dolomite, and argillaceous limestone areas are different. The selected three types (sites) have different lithological features. The T-H type lithology is sandstone, which can usually develop relatively thick soils, and the texture in the humid subtropical region of China is more viscous, resulting in a relatively large soil bulk density. The lithology for type T-L is limestone, which is easily dissolved by water, resulting in a thin layer of soil and small bulk density. The lithology for the $\mathrm{M}$ type is dolomite; dolomite and argillaceous limestone usually form a semi-karst landscape that differs from the karst $[33,34]$. Dolomite belongs to carbonate rocks, which can retain a part of the weathering products, forming a soil thickness and bulk density between those of the former two types. Therefore, under the same climatic conditions, lithology largely determines the soil conditions and thus affects the surface runoff process.

\subsection{Possible Impact of Spatial Scale on Surface Runoff}

In this study, the micro-runoff plot was taken as the unit of study. If the spatial scale is expanded to the slope or the small-watershed scale, the surface runoff characteristics of each landscape type can change substantially. Karst areas contain both surface and subsurface hydrological systems. As the scale of the study is expanded to the slope scale, it is found that surface runoff can penetrate the ground along the rocky fractures at low-lying sites. When the study scale is extended to the small catchment scale, it is found that surface runoff can become groundwater by being diverted into underground rivers along the loopholes and sinkholes. This expansion of the research scale leads to significant changes in surface runoff coefficients and other surface runoff characteristics. Therefore, although there is abundant research on the characteristics of surface runoff, the variations in surface runoff characteristics at different spatial scales in different litter layers and topsoil combination conditions remain the important problems to be solved.

\section{Conclusions}

A case study on three types of litter layer and topsoil combination (T-L, T-H, and M) was conducted to evaluate the characteristics of surface runoff at the plot scale in Guizhou Province, China. The results showed that the runoff volume was the largest for the T-H type under different rainfall intensities and durations. Runoff was the smallest for the T-L type and the increase in runoff with the increase in rainfall duration was also small. Runoff for the $M$ type had similar characteristics to the runoff for the T-L and T-H types. In the early stages of heavy rainfall, the response of surface runoff to rainfall intensity for the $\mathrm{M}$ type was not significant. The runoff yielding speed was significantly higher in the T-H type than in the T-L and $\mathrm{M}$ types, and the runoff yielding time was significantly lower. In general, the runoff coefficient was smallest in the T-L type and largest in the T-H type. Under the 
three rainfall intensities, the variations in the runoff coefficient were $15.6 \%$ for the T-L type, $19.3 \%$ for the T-H type, and 5.8\% for the M type. In the T-L type, the runoff coefficient fluctuated slightly and the runoff coefficients produced by different rainfall intensities at different points in time showed no obvious differences. The results showed that the $\mathrm{M}$ type was between the T-L and T-H types in terms of surface runoff, runoff yielding time, runoff yielding speed, and runoff coefficient. In addition, although soil conditions notably affected surface runoff, it was eventually determined by geological conditions. Further, despite a small number of field experiments, this work enriches knowledge of the effects of different litter and topsoil conditions on runoff processes at the plot scale.

Author Contributions: Q.Z. conceived and designed the experiments; X.Z. and Y.L. conducted the experiments; Q.Z. and M.C. analyzed the data; Q.Z. wrote the paper.

Funding: This work was supported by the Key Project of Science and Technology Program of Guizhou Province: Key Technology and Demonstration for the State Engineering Technology Institute for Karst Desertification Control (Qiankehe Zhongdazhuanxiang Zi [2014] 6007), the National Science Foundation of China (grant Nos. 41761003 and 41601471), the Science and Technology Support Program of Guizhou Province, China (grant No. [2017]2855), the Project for National Top Discipline Construction of Guizhou Province: Geography in Guizhou Normal University (85-01 2017 Qianjiao Keyan Fa), and the Scientific Research Starting Funds for Doctoral Scholars at Guizhou Normal University.

Conflicts of Interest: The authors declare no conflict of interest.

\section{References}

1. Gomyo, M.; Kuraji, K. Effect of the litter layer on runoff and evapotranspiration using the paired watershed method. J. For. Res. 2016, 21, 306-313. [CrossRef]

2. Walsh, R.P.D.; Voigt, P.J. Vegetation litter: An underestimated variable in hydrology and geomorphology. J. Biogeogr. 1977, 4, 253-274. [CrossRef]

3. Gerrits, A.M.J.; Pfister, L.; Savenije, H.H.G. Spatial and temporal variability of canopy and forest floor interception in a beech forest. Hydrol. Processes 2010, 24, 3011-3025. [CrossRef]

4. Li, X.; Niu, J.; Xie, B. Study on hydrological functions of litter layers in north china. PLoS ONE 2013, 8, e70328. [CrossRef] [PubMed]

5. Udom, B.E.; Omovbude, S.; Abam, P.O. Topsoil removal and cultivation effects on structural and hydraulic properties. Catena 2018, 165, 100-105. [CrossRef]

6. Castillo, V.M.; Gomez-Plaza, A.; Martınez-Mena, M. The role of antecedent soil water content in the runoff response of semiarid catchments: A simulation approach. J. Hydrol. 2003, 284, 114-130. [CrossRef]

7. Braud, I.; Desprats, J.F.; Ayral, P.A.; Bouvier, C.; Vandervaere, J.P. Mapping topsoil field-saturated hydraulic conductivity from point measurements using different methods. J. Hydrol. Hydromech. 2017, 65, 264-275. [CrossRef]

8. Liu, W.; Luo, Q.; Lu, H.; Wu, J.; Duan, W. The effect of litter layer on controlling surface runoff and erosion in rubber plantations on tropical mountain slopes, SW China. Catena 2017, 149, 167-175. [CrossRef]

9. Miyata, S.; Kosugi, K.; Gomi, T.; Mizuyama, T. Effects of forest floor coverage on overland flow and soil erosion on hillslopes in Japanese cypress plantation forests. Water Resour. Res. 2009, 45, 192-200. [CrossRef]

10. Prosdocimi, M.; Jordãn, A.; Tarolli, P.; Keesstra, S.; Novara, A.; Cerdã, A. The immediate effectiveness of barley straw mulch in reducing soil erodibility and surface runoff generation in mediterranean vineyards. Sci. Total Environ. 2016, 547, 323-330. [CrossRef] [PubMed]

11. Hueso-González, P.; Ruiz-Sinoga, J.D.; Martínez-Murillo, J.F.; Lavee, H. Overland flow generation mechanisms affected by topsoil treatment: Application to soil conservation. Geomorphology 2015, 228, 796-804. [CrossRef]

12. Sorbotten, L.E.; Stolte, J.; Wang, Y.; Mulder, J. Hydrological Responses and Flow Pathways in an Acrisol on a Forested Hillslope with a Monsoonal Subtropical Climate. Pedosphere 2017, 27, 1037-1048. [CrossRef]

13. Evans, R. Factors controlling soil erosion and runoff and their impacts in the upper Wissey catchment, Norfolk, England: A ten year monitoring programme. Earth Surf. Processes Landf. 2017, 42, 2266-2279. [CrossRef]

14. Mayerhofer, C.; Meißl, G.; Klebinder, K.; Kohl, B.; Markart, G. Comparison of the results of a small-plot and a large-plot rainfall simulator-Effects of land use and land cover on surface runoff in Alpine catchments. Catena 2017, 156, 184-196. [CrossRef] 
15. Zhang, Q.; Jia, X.; Zhao, C.; Shao, M.A. Revegetation with artificial plants improves topsoil hydrological properties but intensifies deep-soil drying in northern Loess Plateau, China. J. Arid Land 2018, 10, 335-346. [CrossRef]

16. Jiang, Z.; Lian, Y.; Qin, X. Rocky desertification in Southwest China: Impacts, causes, and restoration. Earth-Sci. Rev. 2014, 132, 1-12. [CrossRef]

17. Bonacci, O.; Roje-Bonacci, T. Sea water intrusion in coastal karst springs: Example of the Blaž Spring (Croatia). Hydrol. Sci. J. 1997, 42, 89-100. [CrossRef]

18. Ford, D.; Williams, P. Introduction to Karst. In Karst Hydrogeology and Geomorphology; John Wiley \& Sons Ltd.: Hoboken, NJ, USA, 2007; pp. 1-8.

19. Bailey, G.N.; Ioakim, C.; King, G.P.C.; Turner, C.; Sanchez-Goni, F.; Sturdy, D.; Winder, N.P. Norwest epirus in the Palaeolithic. In Understanding the Natural and Anthropogenic Causes of Degradation and Desertification in the Mediterranean Basin; van der Leeuw, S.E., Ed.; EUR 18181 EN; European Communities: Luxembourg, 1998; pp. 329-359.

20. Zhang, D.F.; Wang, S.J.; Zhou, D.Q. Internal driving mechanism of karst rocky desertification in Guizhou Province. Soil Water Conserv. 2001, 21, 1-5. (In Chinese)

21. Chen, S.Z.; Zhou, Z.; Yan, L.; Li, B. Quantitative evaluation of ecosystem health in a karst area of south China. Sustainability 2016, 8, 975. [CrossRef]

22. Cerdà, A. The effect of patchy distribution of Stipa tenacissima L. on runoff and erosion. J. Arid Environ. 1997, 36, 37-51. [CrossRef]

23. Imeson, A.C.; Lavee, H.; Calvo, A.; Cerdà, A. The erosional response of calcareous soils along a climatological gradient in southeast Spain. Geomorphology 1998, 24, 3-16. [CrossRef]

24. Labat, D.; Ababou, R.; Mangin, A. Rainfall-runoff relations for karstic springs. Part ii: Continuous wavelet and discrete orthogonal multiresolution analyses. J. Hydrol. 2000, 238, 149-178. [CrossRef]

25. Li, Z.; Xu, X.; Xu, C.; Liu, M.; Wang, K.; Yu, B. Annual runoff is highly linked to precipitation extremes in karst catchments of southwest China. J. Hydrometeorol. 2017, 18, 2745-2759. [CrossRef]

26. Rooij, R.D.; Perrochet, P.; Graham, W. From rainfall to spring discharge: Coupling conduit flow, subsurface matrix flow and surface flow in karst systems using a discrete-continuum model. Adv. Water Resour. 2013, 61, 29-41. [CrossRef]

27. Wu, L.; Wang, S.; Bai, X.; Luo, W.; Tian, Y.; Zeng, C. Quantitative assessment of the impacts of climate change and human activities on runoff change in a karst watershed, SW China. Sci. Total Environ. 2017, 601-602, 1449-1465. [CrossRef] [PubMed]

28. Calvo-Cases, A.; Boix-Fayos, C.; Imeson, A.C. Runoff generation, sediment movement and soil water behaviour on calcareous (limestone) slopes of some Mediterranean environments in southeast Spain. Geomorphology 2003, 50, 269-291. [CrossRef]

29. Peng, T.; Wang, S.J. Effects of land use, land cover and rainfall regimes on the surface runoff and soil loss on karst slopes in southwest China. Catena 2012, 90, 53-62. [CrossRef]

30. Dai, Q.; Peng, X.; Yang, Z.; Zhao, L. Runoff and erosion processes on bare slopes in the karst rocky desertification area. Catena 2017, 152, 218-226. [CrossRef]

31. Majone, B.; Bellin, A.; Borsato, A. Runoff generation in karst catchments: Multifractal analysis. J. Hydrol. 2004, 294, 176-195. [CrossRef]

32. Li, X.Y.; Contreras, S.; Solé-Benet, A.; Cantón, Y.; Domingo, F.; Lázaro, R. Controls of infiltration-runoff processes in Mediterranean karst rangelands in SE Spain. Catena 2011, 86, 98-109. [CrossRef]

33. Gulley, J.D.; Martin, J.B.; Spellman, P.; Moore, P.J.; Screaton, E.J. Influence of partial confinement and Holocene river formation on groundwater flow and dissolution in the Florida carbonate platform. Hydrol. Processes 2014, 28, 705-717. [CrossRef]

34. Gunn, J.D.; Folan, W.J.; Robichaux, H.R. A landscape analysis of the Candelaria watershed in Mexico: Insights into paleoclimates affecting upland horticulture in the southern Yucatan Peninsula semi-karst. Geoarchaeology 1995, 10, 3-42. [CrossRef]

(C) 2018 by the authors. Licensee MDPI, Basel, Switzerland. This article is an open access article distributed under the terms and conditions of the Creative Commons Attribution (CC BY) license (http://creativecommons.org/licenses/by/4.0/). 